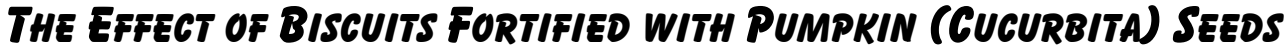 POWDER AND ITS OIL ON FATTY LIVER IN ALBINO RATS
}

$\begin{array}{cc}\text { Ahmed O Shalaby } & \text { By } \\ \text { Department of Home Economics, } & \text { Hanaa F. El-Mehiry } \\ \text { Faculty of Specific Education, } & \text { Department of Home Economics, } \\ \text { Mansoura University. } & \text { Faculty of Specific Education, } \\ \text { Fatma M. El-Zamzamy } & \text { Mansoura University. } \\ \text { Department of Home Economics, } & \text { SalwaA. Ibrahim } \\ \text { Faculty of Specific Education, } & \text { Department of Home Economics, } \\ \text { Mansoura University. } & \text { Faculty of Specific Education, } \\ & \text { Mansoura University. }\end{array}$

Research Gournal Specific Fducation

Faculty of Specific Fducation

gYansoura University

ISSUE NO. 48, OCTOBER. 2017

مجلة بعوث التربية النوعية - جامعة المنصورة

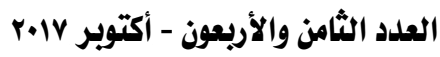




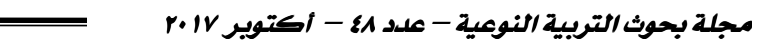

\section{THE EFFECT OF BISCUITS FORTIFIED WITH PUMPKIN (CUCURBITA) SEEDS POWDER AND ITS OIL ON FATTY LIVER IN ALBINO RATS}

\section{Ahmed O Shalaby"}

Fatma M. El-Zamzamy ${ }^{*}$
Hanaa F. El-Mehiry*

SalwaA. Ibrahim *

\section{Abstract}

The aim of this work was to investigate the effect of biscuits fortified with pumpkin (Cucurbita) seeds with $15 \%$ of powder and with $3 \%$ of oil on amitriptyline induced liver in experimental rats. Twenty male rats of Sprague Dawley strain (weighting 190 $\pm 10 \mathrm{~g}$ ) were classified in to four groups ( 5 rats each). The first group fed on standard diet, used as a negative control group (-ve). Fifteen rats were given amitriptyline $(10 \mathrm{mg} / \mathrm{Kg})$ as aqueous solutions that prepared extempore and administered in traperitoneally (i.p) to rats once daily for 14 days . They divided into three groups, positive control group (+ve) the other two groups treated $15 \%$ pumpkin seeds powder biscuits and 3\% pumpkin seeds oil biscuits. for 8 weeks. Rats received amitriptyline only without any treatment showed remarkable increases in serum levels lipid proifil indicating the outset of fatty liver.

Greater raises inactivates of AST and ALT levels in serum were observed in positive control rats compared with those in normal control group. Treatment with 15\% pumpkin seeds powder biscuits and 3\% pumpkin seeds oil biscuits decreased the levels of serum cholesterol (TC), triglycerides (TG), high density lipoprotein (HDL-c), low density lipoprotein (LDL-c) and very low density lipoprotein (VLDL-c) in serum linked with reduction in the activity of serum AST and ALT. Also the results observed in groups treatment with $15 \%$ pumpkin seeds powder biscuits and 3\% pumpkin seeds oil biscuits showed remarkable increases in total antioxidants, Superoxide dismutase (SOD), weight gain, food intake , food efficiency and HDL-c. Also decreased the levels of nitric oxide (NO)

* Department of Home Economics, Faculty of Specific Education, Mansoura University. 
compared with positive control rats .These results suggest that biscuits fortified with both of pumpkin seeds powder and its oil can be used as health food with functional properties for treatment of fatty liver induced by amitriptyline.

Key of words: Fatty liver - Lipid profile - Amitriptyline- Pumpkin seeds - Total antioxidants.

\section{Introduction}

Liver is an important organ in our body and has major multiply functions, such as protein synthesis, detoxification of various metabolites and the production of necessary biochemical's that very vital for digestion. It also plays a major role in regulation of glycogen storage, metabolism, hormone production and decomposition of red blood cells. Also liver has great role in lipid metabolism. it performs lipogenesis, cholesterol synthesis, triglycerides production, and a bulk of the body's lipoproteins are synthesized in the liver (Fong, et al. , 2015). Nonalcoholic fatty liver disease (NAFLD) is one of the most common causes of chronic liver damage in various countries. It has a broad pathologic spectrum which ranges from simple fatty infiltration of the liver (Chidambaram, 2010). NASH is considered as one of the risk factors for cardiovascular diseases like arteriosclerosis where elevation of oxidative stress, inflammation and levels of plasma TG, LDL-Ch and total cholesterol result from the increased synthesis and accumulation of cholesterol and fat in liver during NASH (AlOkbi, et al ., 2013).

Fatty liver is considered as the hepatic component of metabolic syndrome and its prevalence is continually increasing due to increased incomes of obesity. Fatty liver itself does not represent any hazards on health, but the condition that fatty liver changing to steatohepatitis is considered as a great health problem that needs combating to .steatohepatitis is one of the vital reasons of cardiovascular disease and liver dysfunctions (Al-Okbi, et al. , 2015).

Amitriptyline is one of drugs called tricyclic antidepressants (TCAs) and is use in treating depression (Dennisl, 2015). Amitriptyline caused 
raising in liver function biomarkers in patients that received it continuously (Gossell, 2008).

The pumpkin plant is a native of Asia, however, it is now grown extensively in several of the temperate and warmer climates of the world. Species of pumpkin available like, cucurbitapepo, cucurbita maxima and cucurbita stilbo. Pumpkins are medicinally defined as round in shape and orange in color, and like other winter squash, have long vines and a flowering stage (Marr, et al. , 2004).

Pumpkin seed has an essential role as a source of proteins, carbohydrates, lipids and other nutrients in human diet which are needful for protecting proper health. Cucurbita maxima seed may be necessary and economical source of minerals, proteins, vitamins, and calories which are substantial for human nutrition (Alfawaz, 2004).

Pumpkin seeds oil is a rich source of phenolic components, $\beta$ carotene, tocopherol, sterols , and unsaturated fatty acids. Unsaturated fatty acids are the major fatty acids in pumpkin oil like linoleic acid and oleic acid (Chopra and Sambaiah, 2009) The effective of pumpkin seeds might be due to the presence of unsaturated fatty acids, phytosterol, antioxidant vitamins like carotenoids, tocotrienols and tocopherol (Barakat and Mahmoud, 2011 and Butinar, et al ., 2011 and Hanaa and Rehab, 2015).

This study is designed to evaluate the effect of fortification of biscuits with pumpkin seeds powder and oil on fatty liver induced by amitriptyline in albino rats.

\section{Materials and Methods:-}

\section{Materials:-}

Pumpkin (Cucurbita) seeds, Wheat flour (72\% extraction), Sugar, Salt and corn oil were purchased from local market of different areas in Mansoura City, Egypt. Pumpkin seeds oil was obtained from Arab Company for Pharmaceutical and Medicinal Plants, Amitriptyline drug produced by Kahira /MSD Company for Pharmaceuticals and Medicinal 
Egypt. Twenty male albino rats of Sparague Dawley strain, (weight $190 \pm 10$ g) were obtained from the National Research Centre, Cairo, Egypt.

\section{Methods:-}

Biscuits preparing process: Biscuits with the substituted level of. $15 \%$ of pumpkin seeds powder and with replacement of oil (3\%) with pumpkin seeds oil were prepared according to Vasantharuba, et al. , (2012). Biscuits were processed using the method described by A.A.C.C. (2000). using wheat flour ( $72 \%$ extraction), samples replaced separately with 15 and $3 \%$ pumpkin seeds oil.

Proximate analysis: The proximate nutritional qualities of the biscuits samples were carried out according to the method of Erukainure, et al. , (2013) which covers for total protein, ash, fat, dietary fiber, and carbohydrates, respectively.

\section{Experimental:}

Rats were purchased from the animal house of National Research Center, Cairo, Egypt. All animals were calcified to four groups five rats each with wire bottoms and fed on basal diet which formulated according to AIN (1993) for one week for adaption. The animals were kept under standard environmentally controlled, clean-air room with temperature of 24 $\pm 5^{\circ} \mathrm{C}$, illumination ( $12 \mathrm{~h}$ light $/ 12 \mathrm{~h}$ dark cycles), a relative humidity of $60 \pm$ $4 \%$, and water and basal diet were available ad-libitum throughout the period of 8 weeks of the investigation. 5 rats used as normal control group (ve), the other rats were given amitriptyline $(10 \mathrm{mg} / \mathrm{Kg})$ as aqueous solutions which prepared ex tempore and administered intraperitoneally (i.p) to rats once daily for 14 days separated or combined in the constant volume of 5 $\mathrm{ml} / \mathrm{Kg}$. Rats were classified as the following:-

- Group (1); Normal control group (-ve) fed on standard diet.

- Group (2); positive control (+ve) group fed on standard diet and amitriptyline .

- Group (3): Treated group fed on standard diet with (biscuits fortified with $15 \%$ pumpkin seeds powder).

- Group (4): Treated group fed on standard diet with (biscuits fortified with3\% pumpkin seeds oil). 
Rats were subjected daily to physical examination for observation of healthy condition. Food intake was reported daily and body weight of rats was measured using a triple beam balance twice weekly. Food efficiency ratio was calculated at the final of experiment as following:-Food efficiency ratio $(F E R)=$ body weight (g) / food intake (g). At the final of the experimental period the animals were fasted overnight and then the rats were sacrificed. Samples of blood were collected from the aorta of each rat and withdrawn in test tubes. The tubes of blood were left for coagulation and centrifuged to obtain serum for further analysis.

\section{Biochemical parameters:}

levels of (TC), (TG) and (HDL-c) in serum were measured by using the spinreact enzymatic kits according to Cohn, et al ., (1988) and Foster and Dumns (1973) and Young (1995), respectively. (LDL-c) and (VLDLc) were calculated by the method reported by Fried, et al. , (1972). Serum aspartate and alanine amino transferase (AST and ALT) were determined like the method reported by Young (2001) and Burits and Ashwood (1999), respectively. Serum Creatinine, and Uric Acid were enzymetically determined according to Bohmer (1971), Fossati, et al ., (1980) and Patton and Crouch (1977), respectively. Superoxide Dismutase (SOD) activity and Total Antioxidants Capacity (TAC) were calculated according to Nishikimi, et al ., (1972) and Cao, et al ., (1993).

Statistical analysis: The obtained data were presented as mean \pm standard deviation. Data were analyzed using computerized SPSS (Statistic Program Sigma stat, Statistical Soft-Ware, SAS Institute, Cary, NC). Differences between normal control and Amitriptyline groups were analyzed by one way ANOVA (Analysis of variance) test using Duncan's multiple range test and $\mathrm{p}<0.05$ was used to indicate significance between different groups (Snedecor and Cochran 1967).

\section{Results and Discussion:-}

1- Proximate composition of biscuits fortified with pumpkin seeds powder and oil. 
Table (1) summarizes the results of proximate analysis of biscuits fortified with $15 \%$ pumpkin seeds powder and 3\% pumpkin seeds oil .Data showed that biscuits Fortified with 15\% PSP (pumpkin seeds powder) and biscuits fortified with 3\% PSO (pumpkin seeds oil) recorded the contains of moisture (4.45 \& 5.21\%) and ash of (1.84 \& 1.69\%). Organic Matter, crud fiber, ether Extract, crud protein and carbohydrate which recorded that (98.16 \& 98.31\%), (0.52 \& 0.52\%), (23.98 \& 19.33\%), (12.61\& 12.68\%) and $(61.05 \& 65.78 \%)$, respectively. results at agreement with (Barakat and Mahmoud 2011 and Butinar, et al ., 2011) who reported that pumpkin seeds a rich source of different nutrients.

Table (1): Proximate composition of biscuits fortified with pumpkin seeds powder and oil .

\begin{tabular}{|c|c|c||}
\hline Parameter / Samples & \multicolumn{2}{|c|}{$\begin{array}{r}\text { Biscuits fortified with } \\
\mathbf{1 5 \%} \text { PSP 3\% PSO }\end{array}$} \\
\hline \hline Dry Matters \% & 95.55 & 94.79 \\
\hline moisture \% & 4.45 & 5.21 \\
\hline Ash \% & 1.84 & 1.69 \\
\hline Organic Matter \% & 98.16 & 98.31 \\
\hline Crud fiber \% & 0.52 & 0.52 \\
\hline Ether Extract \% & 23.98 & 21.93 \\
\hline Crud protein\% & 12.65 & 12.70 \\
\hline Nitrogen free Extract \% & 62.85 & 66.78 \\
\hline Growth energy MJ/Kg & 23.51 & 22.47 \\
\hline \hline
\end{tabular}

Each value represents the mean $\pm \mathrm{SD}$,

Mean values in each column having different superscript $(a, b, c, .$.$) are$ significant at $\mathbf{p}<0.05$ by different and vice versa .

PSP: Pumpkin seeds powder biscuits, PSO: Pumpkin seeds oil biscuits.

\section{2- Changes in nutritional status indicators of fatty liver rats:}

The positive control rats showed significant lowering in weight gain and food intake at $\mathrm{p} \square 0.05$ (Table 2) compared to normal control group. Also positive control rats group was found to be significantly lower in weight gain, food intake and food efficiency ratio (FER) at $\mathrm{p} \square 0.05$ than treated rat groups feeding on biscuits fortified with (15\% PSP and 3\% PSO). 
But no significant difference was observed in body weight gain, food intake and FER between normal control group and both treated group consumed $15 \%$ PSP and 3\% PSO in amitriptyline rats. However positive control group had significant increase in the previous parameters comparing to all groups. These results are the same trend with the finding of José and Donald (1987) and Hanaa and Rehab (2015) they reported that amitriptyline induce weight loss in a significant proportion of patients.

Table (2): Effect of biscuit fortified with 15\% pumpkin seeds powder and $3 \%$ pumpkin seeds oil on initial weight, final weight, weight gain, food intake, food efficiency ratio and liver weight in fatty liver rats.

\begin{tabular}{|c|c|c|c|c|}
\hline \multirow{2}{*}{ Variables } & \multirow{2}{*}{$\begin{array}{l}\text { Normal } \\
\text { control }\end{array}$} & \multirow{2}{*}{$\begin{array}{l}\text { Positive } \\
\text { control }\end{array}$} & \multicolumn{2}{|c|}{ Treated groups } \\
\hline & & & $15 \%$ PSP & $3 \%$ PSO \\
\hline \multirow{2}{*}{ Initial weight (g) } & 188.05 & 188.00 & 188.25 & 190.00 \\
\hline & $5.70 \mathrm{a}$ & $5.16 \mathrm{a}$ & $5.62 \mathrm{a}$ & $3.09 \mathrm{a}$ \\
\hline \multirow{2}{*}{ Final weight (g) } & $235.75 \pm$ & $217.00 \pm$ & $228.05 \pm$ & $232.00 \pm$ \\
\hline & $11.35 \mathrm{a}$ & $10.52 \mathrm{c}$ & $11.42 \mathrm{~b}$ & $11.82 \mathrm{a}$ \\
\hline \multirow{2}{*}{ Weight gain (g) } & $47.25 \pm$ & $29.00 \pm$ & $40.25 \pm$ & $42.00 \pm$ \\
\hline & $4.06 \mathrm{a}$ & $1.82 \mathrm{~d}$ & $3.69 \mathrm{c}$ & $3.82 \mathrm{~b}$ \\
\hline \multirow{2}{*}{ Food intake (g) } & $15.25 \pm$ & $11.50 \pm$ & $15.50 \pm$ & $15.50 \pm$ \\
\hline & $1.25 \mathrm{a}$ & $1.29 \mathrm{~b}$ & $1.95 \mathrm{a}$ & $1.73 \mathrm{a}$ \\
\hline \multirow{2}{*}{$\begin{array}{c}\text { Food efficiency } \\
\text { ratio (FER) }\end{array}$} & $0.33 \pm$ & $0.24 \pm$ & $0.30 \pm$ & $0.31 \pm$ \\
\hline & 0.001 a & 0.002 b & 0.001 a & 0.002 a \\
\hline \multirow{2}{*}{$\begin{array}{c}\text { Liver weight } \\
\text { (g) }\end{array}$} & $4.78 \pm$ & $2.94 \pm$ & $3.97 \pm$ & $4.17 \pm$ \\
\hline & $0.30 \mathrm{a}$ & $0.59 \mathrm{~b}$ & 0.05 a & $0.23 \mathrm{a}$ \\
\hline
\end{tabular}

Each value represents the mean $\pm \mathrm{SD}$,

Mean values in each column having different superscript $(a, b, c, .$.$) are$ significant at $\mathbf{p}<0.05$ by different and vice versa .

PSP: Pumpkin seeds powder biscuits, PSO: Pumpkin seeds oil biscuits.

\section{3- Serum lipid profile in fatty liver rats:}

Table 3 showed significant increase of TC, TG, LDL-c, total lipid and VLDL-c levels in positive control group when compared with normal control rat group ( $\mathrm{p} \square 0.05$ ). However there was a significant reduction in 
TC, TG, LDL-c, total lipids and VLDL-c levels of treated rat groups with biscuits fortified that substituted at 15\% PSP and 3\% PSO when compared with positive control ( $\mathrm{p} \square 0.05$ ). However there is no significant difference was found between rats group fed on (3\% PSO) and normal control rat group in LDL-c and VLDL-c concentrations. Results show significant increase in level of HDL-c of rats group fed on (biscuits fortified with $3 \%$ PSO) when compared to positive control group .Induction of fatty liver by amitriptyline associated with significant increases in total cholesterol, triglycerides and LDL-c levels in agreement with the findings of Al-Okbi, et al ., (2013). Furthermore Farid, et al ., (2015) reported that pumpkin seeds administration caused reduction in TC, TG and LDL-c concentrations This effect was striebuted content of unsaturated fatty acids in the seeds .

Table (3):Effect of biscuits fortified with 15\% pumpkin seeds powder and 3\% pumpkin seeds oil on serum lipids levels (mg/dl) of fatty liver rats.

\begin{tabular}{|c|c|c|c|c|}
\hline & Normal & Positive & Treated gI & Ips \\
\hline & control & control & $15 \%$ PSP & $3 \%$ PSO \\
\hline $\begin{array}{l}\text { TC } \\
\mathrm{mg} / \mathrm{dl}\end{array}$ & $\begin{array}{l}63.80 \pm \\
9.34 \mathrm{c} \\
\end{array}$ & $\begin{array}{l}107.55 \pm \\
12.75 \text { a }\end{array}$ & $\begin{array}{l}84.31 \pm \\
7.43 \text { b }\end{array}$ & $\begin{array}{l}68.02 \pm \\
6.41 \mathrm{c} \\
\end{array}$ \\
\hline $\begin{array}{l}\text { TG } \\
\mathrm{mg} / \mathrm{dl}\end{array}$ & $\begin{array}{l}95.77 \pm \\
9.49 d\end{array}$ & $\begin{array}{l}149.38 \pm \\
11.61 \mathrm{a}\end{array}$ & $\begin{array}{l}127.07 \pm \\
10.21 \text { b }\end{array}$ & $\begin{array}{l}92.51 \pm \\
7.53 \mathrm{c}\end{array}$ \\
\hline $\begin{array}{l}\text { HDL-c } \\
\mathrm{mg} / \mathrm{dl}\end{array}$ & $\begin{array}{l}37.57 \pm \\
3.71 \text { a }\end{array}$ & $\begin{array}{l}26.15 \pm \\
2.43 \mathrm{c}\end{array}$ & $\begin{array}{l}32.02 \pm \\
1.75 \mathrm{~b}\end{array}$ & $\begin{array}{l}34.12 \pm \\
2.42 \mathrm{~b}\end{array}$ \\
\hline $\begin{array}{l}\text { LDL-c } \\
\mathrm{mg} / \mathrm{dl}\end{array}$ & $\begin{array}{l}22.77 \pm \\
2.04 \mathrm{c}\end{array}$ & $\begin{array}{l}41.30 \pm \\
3.92 \mathrm{a}\end{array}$ & $\begin{array}{l}30.32 \pm \\
2.66 \text { b }\end{array}$ & $\begin{array}{l}22.77 \pm \\
2.88 \mathrm{c}\end{array}$ \\
\hline $\begin{array}{l}\text { Total lipid } \\
\text { mg/dl }\end{array}$ & $\begin{array}{l}223.92 \pm \\
11.83 \mathrm{~d}\end{array}$ & $\begin{array}{l}333.32 \pm \\
12.10 \mathrm{a}\end{array}$ & $\begin{array}{l}275.35 \pm \\
11.10 \mathrm{~b}\end{array}$ & $\begin{array}{l}229.88 \pm \\
10.11 \mathrm{c}\end{array}$ \\
\hline $\begin{array}{l}\text { VLDL-c } \\
\mathrm{mg} / \mathrm{dl}\end{array}$ & $\begin{array}{l}19.15 \pm \\
1.90 \mathrm{~d}\end{array}$ & $\begin{array}{l}29.68 \pm \\
2.32 \mathrm{a}\end{array}$ & $\begin{array}{l}25.41 \pm \\
2.04 \mathrm{~b}\end{array}$ & $\begin{array}{l}18.50 \pm \\
1.51 \mathrm{c}\end{array}$ \\
\hline
\end{tabular}

Each value represents the mean \pm SD..

Mean values in each column having different superscript $(a, b, c, .$.$) are$ significant at $\mathbf{p}<0.05$ by different and vice versa.

PSP: Pumpkin seeds powder biscuits, PSO: Pumpkin seeds oil biscuits.

TC: Total Cholesterol, TG: Triglycerides, HDL-c: High density lipoprotein, LDL-C: Low density lipoprotein, VLDL-c: Very low density lipoprotein. 


\section{4- Liver and kidney functions in fatty liver rats}

Table 4 shows liver function, it was obvious that amitriptyline group (positive control) showed significant increase in ALT and AST activities comparing to normal control animals. However after feeding on biscuits fortified with both $15 \%$ pumpkin seeds powder and 3\% pumpkin seeds oil ALT and AST levels were reduced when compared with amitriptyline group. Previous studies indicated that amitriptyline caused significant elevation in activities of serum AST and ALT that linked with hepatic dysfunction (Afify, et al . , 2009). However after treatment with both biscuits fortified with pumpkin seeds powder and oil the elevated activities of ALT and AST successfully ameliorated. Concerning serum enzymes related to kidney function, administration of amitriptyline exhibited significant increase $(\mathrm{p}<0.05)$ in Creatinine, Uric acid and Urea comparing with normal control group. However treated rat group G2 feeding on biscuits fortified with 3\% PSO significantly reduced ( $\square \square 0.05$ ) uric acid and urea levels to a level similar to normal control rat group. The present work showed that feeding of biscuits fortified with both of 15\% PSP and 3\% PSO effectively lowered the activities of AST and ALT and improved liver function. These results are in the same trend with Nkosi, et al ., (2005) and Oboh (2005) who observed that the administration of pumpkin seeds caused a significant lowering in AST and ALT activities. In addition Farid, et al . , (2015) reported that the treatment with pumpkin seeds restored liver enzymes activities, and related the effect to high contents of phenolic and flavonoids compounds which protect liver cell from damage. 
- The Effect of Biscuits Fortified with Pumpkin (Cucurbita) Seeds Powder and its Oil on Fatty Liver

Table (4): Effect of biscuits fortified with $15 \%$ pumpkin seeds powder and $3 \%$ pumpkin seeds oil on some liver and kidney function parameters in fatty liver rats.

\begin{tabular}{|c|c|c|c|c|}
\hline \multirow{2}{*}{ Variables } & \multirow{2}{*}{ Normal control } & \multirow{2}{*}{ Positive control } & \multicolumn{2}{|c|}{ Treated groups } \\
\hline & & & $15 \%$ PSP & $3 \%$ PSO \\
\hline $\begin{array}{l}\text { AST } \\
(\mathbf{I u} / \mathbf{m l}) \\
\end{array}$ & $\begin{array}{l}27.52 \pm b \\
2.16 \mathrm{~d}\end{array}$ & $\begin{array}{l}45.12 \pm b \\
3.21 \mathrm{a}\end{array}$ & $\begin{array}{l}33.80 \pm b \\
2.76 b\end{array}$ & $\begin{array}{l}29.17 \pm b \\
1.66 \text { bc }\end{array}$ \\
\hline $\begin{array}{l}\text { ALT } \\
(\mathbf{I u} / \mathbf{m l}) \\
\end{array}$ & $\begin{array}{l}16.55 \pm b \\
1.95 \mathrm{~d}\end{array}$ & $\begin{array}{l}30.37 \pm b \\
3.43 a\end{array}$ & $\begin{array}{l}24.22 \pm b \\
2.11 b\end{array}$ & $\begin{array}{l}19.25 \pm b \\
1.80 \mathrm{c}\end{array}$ \\
\hline $\begin{array}{l}\text { Creatinin } \\
\mathrm{mg} / \mathrm{dl}\end{array}$ & $\begin{array}{l}0.85 \pm \mathbf{c} \\
0.02 \mathrm{~d}\end{array}$ & $\begin{array}{l}2.74 \pm c \\
0.21 a\end{array}$ & $\begin{array}{l}1.94 \pm \mathbf{c} \\
0.11 \mathrm{~b}\end{array}$ & $\begin{array}{l}0.94 \pm b \\
0.04 \text { c }\end{array}$ \\
\hline $\begin{array}{l}\text { Uric acid } \\
\mathrm{mg} / \mathrm{dl}\end{array}$ & $\begin{array}{l}2.12 \pm \\
0.33 \mathrm{c}\end{array}$ & $\begin{array}{l}4.44 \pm \\
0.33 \text { a }\end{array}$ & $\begin{array}{l}3.08 \pm \\
0.19 \text { b }\end{array}$ & $\begin{array}{l}2.15 \pm \\
0.28 \mathrm{c}\end{array}$ \\
\hline $\begin{array}{l}\text { Urea } \\
\mathrm{mg} / \mathrm{dl}\end{array}$ & $\begin{array}{l}24.80 \pm b \\
1.26 \mathrm{c}\end{array}$ & $\begin{array}{l}48.10 \pm b \\
3.08 \text { a }\end{array}$ & $\begin{array}{l}27.85 \pm b \\
2.17 \text { b }\end{array}$ & $\begin{array}{l}24.75 \pm b \\
1.19 c\end{array}$ \\
\hline
\end{tabular}

Each value represents the mean \pm SD.

Mean values in each column having different superscript $(a, b, c, .$.$) are$ significant at $\mathbf{p}<0.05$ by different and vice versa.

PSP: Pumpkin seeds powder biscuits, PSO: Pumpkin seeds oil biscuits.

AST: Aspartate amino transferase, ALT: Alanine amino transferase.

5- Effects of biscuits fortified with 15\% PSP and 3\% PSO on total antioxidant capacity, superoxide dismutase (SOD) and nitric acid (NO) levels in serum of fatty liver rats:

Result postulated in Table 5 revealed that concentration of total antioxidants and SOD for normal control rats were $4.01 \mathrm{mmol} / \mathrm{L}$ and $72.43 \mathrm{U}$ / $\mathrm{mL}$ respectively, while the corresponding levels for positive control group were lower (1.12 $\mathrm{m} \mathrm{mol} / \mathrm{L}$ and $32.25 \mathrm{U} / \mathrm{mL}$ respectively).

Results found a significant increase in total antioxidants and SOD levels and a significant decrease in NO level in biscuits fortified with $15 \%$ PSP and 3\% PSO (Table 5) as compared to the positive control rats. The treated rat group feeding on biscuits fortified with 3\% PSO had the highest total antioxidants and (SOD) levels which was similar to the levels of 
normal control rats followed by treated group feeding on biscuits fortified with 15\% PSP. Diet fortification with both pumpkin seeds powder and oil at examined levels to diet caused an increase in antioxidant parameters such as TAC, SOD and NO levels. biscuits fortified of both pumpkin seeds powder and oil at examined levels increase the activities of antioxidant enzymes. It has been mentioned that the antioxidant activity of plants might be due to their phenolic compounds (Hatapakki, et al . , 2005). Our results are in accordance with the finding of Mangge, et al ., (2014) who reported that the seeds of pumpkin contains powerful antioxidant such as vitamin $\mathrm{E}$ and carotenoids. Therefore pumpkin seeds improve the antioxidants defense system by promoting the activity of antioxidant enzymes. These findings are in line with Taziki, et al , (2015) who reported that antioxidants enzymes levels were diminished obviously when hepatocytes were treated with amitriptyline.

Table (5): Total antioxidant capacity, Superoxide dismutase (SOD) and nitric oxide (NO) in fatty liver rats

\begin{tabular}{||l|l|l|l|l||}
\hline \multirow{2}{*}{ Variables } & \multirow{2}{*}{ Groups } & \multirow{2}{*}{$\begin{array}{l}\text { Normal } \\
\text { control }\end{array}$} & \multirow{2}{*}{$\begin{array}{l}\text { Positive } \\
\text { control }\end{array}$} & \multicolumn{2}{|l|}{ Treated } \\
\cline { 4 - 5 } & & & $\mathbf{1 5 \%}$ PSP & $\mathbf{3 \%}$ PSO \\
\hline \hline Total antioxidants & $4.01 \pm$ & $1.51 \pm$ & $3.35 \pm$ & $3.93 \pm$ \\
$\mathrm{mmol} / \mathrm{L}$ & $0.22 \mathrm{a}$ & $0.16 \mathrm{c}$ & $0.07 \mathrm{bc}$ & $0.07 \mathrm{~b}$ \\
\hline Superoxide dismutase & $72.43 \pm$ & $23.64 \pm$ & $65.85 \pm$ & $70.28 \pm$ \\
$(\mathrm{SOD}) \mathrm{U} / \mathrm{mL}$ & $5.22 \mathrm{a}$ & $4.17 \mathrm{c}$ & $6.85 \mathrm{c}$ & $7.53 \mathrm{~d}$ \\
\hline \multirow{2}{*}{$\mathrm{NO}(\mu \mathrm{mol} / \mathrm{l})$} & $3.48 \pm$ & $14.15 \pm$ & $3.27 \pm$ & $3.39 \pm$ \\
& $0.33 \mathrm{~b}$ & $1.49 \mathrm{a}$ & $1.04 \mathrm{~b}$ & $1.05 \mathrm{~b}$ \\
\hline
\end{tabular}

Each value represents the mean \pm SD.

Mean values in each column having different superscript $(a, b, c, .$.$) are$ significant at $\mathbf{p}<0.05$ by different and vice versa.

PSP: Pumpkin seeds powder biscuits, PSO: Pumpkin seeds oil biscuits.

\section{Conclusion:-}

Our results confirmed that the biscuits fortified evaluated in this study $(15 \%$ pumpkin seeds powder and of 3\% pumpkin seeds oil) are 
effective in improving liver function and ameliorative the lipid profile so pumpkin seeds had a therapeutic protective effect against fatty liver which can serve as a functional food in the management of the disease. The protective effect is revealed by reduction in lipids levels, lowering serum AST and ALT activities. This could be attributed to the bioactive components and total antioxidants presented in pumpkin seeds. So addition of pumpkin seeds powder and pumpkin seeds oil to different food products are recommended for prospective resistance against fatty liver.

\section{REFERNENCES:}

- A.A.C.C, (2000). Approved Method of the AACC, 10th ed., American Association of Cereal Chemists, St., Paul, Minnesota, USA, 2000.

- Afify, M; Abd Elmaksoud M.D; Mosa, T; Elshaer, M. and Kotb, N. (2009) Differential effects of amitriptyline treatment on testicular and liver functions. International Journal of Integrative Biology. 8(1), 50-55.

- AIN,( 1993) . American Institute of Nutrition (AIN), Purified diet for Laboratoy Rodent. J .Nutr., 123:1939-1951.

- Alfawaz MA (2004) Chemical composition and oil characteristics of pumpkin (Cucurbita maxima) seed kernels. Food Science and Agriculture Research Center, King Saud University, Saudi Arabia.(129); 5-18

- Al-Okbi SY; Mohamed DA; Hamed TE. and Edris AE. (2013). Potential protective effect of Nigella sativa crude oils towards fatty liver in rats. Eur. J. Lipid Sci. Technol., , 115, 774-782.

- Al-Okbi SY; Mohamed DA; and Hamed TE (2015) Evaluation of the therapeutic effect of Nigella sativa crude oil and its blend with omega-3 fatty acid-rich oils in a modified hepatorenal syndrome model in rats", Grasas yAceites.

- Barakat L.A. and Mahmoud R.H., (2011) The anti atherogenic, renal protective and immunomodulatory effects of purslane, pumpkin and flax seeds on hypercholesterol -emic rats. N. Am. J.Med. Sci., , 3, 411-417.

- Bohmer, H., (1971). Micro-determination of creatinine. Clin. Chem. Acta.; 32:81-85.

- Burtis, C.A. and Ashwood, E.R.( 1999). Tietz textbook of clinical chemistry, 3rd ed. Philadelphia: WB Saunders, 265-309. 
- Butinar, B;Bucar-Miklavcic M. and Mariani, C. (2011) New vitamin E isomers (gamma-tocomonoenol and alpha-tocomonoenol) in seeds, roasted seeds and roasted seeds oil from the Slovenian pumpkin variety 'Slovenskagolica'. Food Chemistry, (128), 2, (505-512).

- Cao, G; Alessio, H.M. and Cutler, R.G.(1993). Oxygen-radical absorbance capacity assay for antioxidants. Free Radical Biology and Medicine 14, 303-311.

- Chidambaram, J. (2010). Cissus quadrangularis stem alleviates insulin resistance, oxidative injury and fatty liver disease in rats fed high fat plus fructose diet ,Food and Chemical Toxicology. 48(8-9);2021-9.

- Chopra R. and Sambaiah K.,( 2009) Effects of rice bran oil enriched with n-3 PUFA on liver and serum lipids in rats. Lipids, , 44, 37-46.

- Cohn, J. S; McNamara, J.R. and Schaefer, E.J. ( 1988). Lipoprotein cholesterol Concentrations in the plasma of human subjects as measured in the fed and fasted states. Clinical Chemistry, 34, 2456 -2459.

- Dennisl Lee, (2015). Drug induced liver Disease. FDA Prescribing Information. journal of clinical and translational Hepatology.28;3 (2);99-108.

- Erukainue, O.L;.Ebuehi, O.A.T; Adebo ,N; kafor F.O; Hafizur, R.M; Aliyu M. and lemo ,G.N.E (2013). Anti-diabetic and hypoglycemic properties of fiber-enriched cake in alloxan-induced diabetic rats. Mediterranean journal of Nutrition and Metabolism.

- Farid, H. E. A; Salah M. EL-Sayed, and Medhat M. Abozid, (2015). Pumpkin and sunflower seeds attenuate hyperglycemia and protect liver in alloxan-induced diabetic rats. research journal of pharmaceutical, biological and chemical sciences. 6(5). 1269-1279.

- Fong Y; Dupuy D E; Feng M and Abou-Alfa G. (2015). Cancer of the liver. DeVita VT Jr, Lawrence TS, \& Rosenberg SA. Canadian Cancer Society". Cancer.ca. Retrieved -06-26.

- Fossati, P; Prencipe, L. and Berti, G. (1980). Use of 3,5-dichloro-2-hydroxy benzene sulfonic acid/4-amino phenazone chromogenic system in direct enzymic assay of uric acid in serum and urine. Clin. Chem. 26, 227- 231. 
- The Effect of Biscuits Fortified with Pumpkin (Cucurbita) Seeds Powder and its Oil on Fatty Liver

- Foster, L.B. and Dumns, R.T. (1973) . Stable reagents for determination of serum triglycerides by colorimetric condensation method. Clin. Chem. Acta.; 19:338-340.

- Friede wald, W.T; Levy, R.I. and Fredrickson, D.S. (1972) . Estimation of the concentration of low-density lipoprotein cholesterol in plasma, without use of the preparative ultracentrifuge. Clin. Chem.; 18, 499-502.

- Gossell - Williams, M, ( 2008 ) supplementation with pumpkin seeds oil improves plasma lipid profile and cardiovascular outcomes of female non ovariectomized and ovariectomized Sprague dawley rats Phytotherapy Research.

- Hanaa, F.EL Mehiry and Rehab, I. Tag ALDeen (2015) The effect of pumpkin seeds oil on zinc Deficient-Induced Reproductive disorders in Male Rats. Journal of studies and searches of specifie Education, (1);(2);111-131.

- Hatapakki B C;Suresh H M; Bhoomannavar Vand Shivkumar SI( 2005). Effect of Casciaauriculata Linn flowers against alloxan induced diabetes in rats. A J Nat Remedies;5:132-6.

- José, N.Nobrega and Donald V.Coscina (1987). Effects of chronic amitriptyline and desipramine on food intake and body weight in rats.Pharmacology Biochemistry and Behavior 27, 1; 105-112

- Mangge H; Becker K; Fuchs D and Gostner J M (2014). Antioxidants, inflammation and cardiovascular disease. World J Cardiol.26;6(6):462-77.

- Marr, C; Schaplowsky,T and Carey, T. (2004). Commercial vegetable production: Pumpkins. Kansas State University Agricultural Experiment Station and Cooperative Extension Service. Retrieved from www.oznet.ksu.edu.

- Nishikimi M; Appaji, N. and Yagi, K. (1972) .The occurrence of superoxide anion in the reaction of reduced phenazinemethosulfate and molecular oxygen. Biochem Biophys Res Commun. 46: 849-854.

- Nkosi, C.Z; Opoku A.R and Terblanche S.E (2005). Effect of pumpkin seeds (Cucurbitapepo) protein isolate on the activity levels of certain plasma enzymes in CCl4-induced liver injury in low protein fed rats. Phytother Res 19:341-345

- Oboh ,G., (2005). Hepato protective property of ethanolic and aqueous extracts of fluted pumpkin (Telfairiaoccidentalis) leaves against garlic-induced oxidative stress. J Med Food;8(4):560- 
مجلة بحوث التربية النوعية - عدد

- Patton, C.J., and Crouch, S.R.( 1977). Enzymatic colorimetric method for determination of urea in serum. Anal. Chem.; 49: 464-465.

- Snedecor, G.W., and Cochran, W.G. (1967). Statistical Methods; 7th Ed., The Lowa State University Press., Ames, Lowa, U.S.A.

- Taziki, S., Sattari, M. R. Dastmalchi, S. and Eghbal, M. A. (2015). Cytoprotective Effects of Melatonin Against Amitriptyline-Induced Toxicity in Isolated Rat Hepatocytes. Adv Pharm Bull, 5(3), 329-334.

- Vasantharuba Seevaratnam, P. Banumathi, M.R. Premalatha, S.P. Sundaram and

- T. Arumugam, (2012) . Studies on the Preparation of Biscuits Incorporated with Potato Flour. World Journal of Dairy \& Food Sciences 7 (1): 79-84,

- Young, D. S.,( 1995). Effect of drugs on clinical tests, 4th ed. AACC Press

- Young, D. S., (2001). Effects of disease on Clin. Lab. Tests, 4th ed AACC. 


\section{تأثير تدعيم البسكويت بمسحوق وزيت بذور القرع العسلي \\ على الفئران المصابة بالكبد الدهني}

$$
\text { الملخص العرببي }
$$

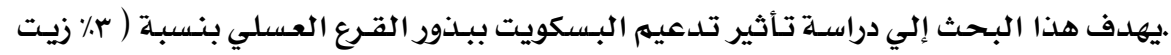

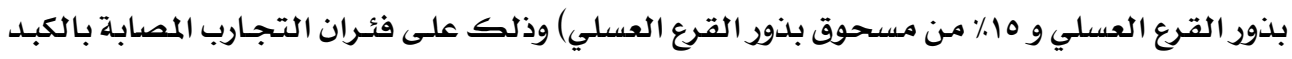

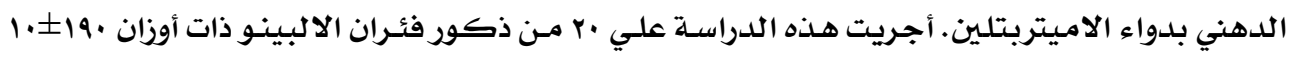

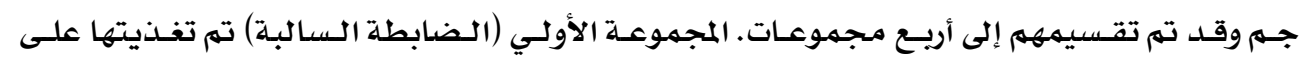

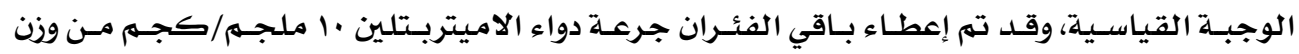

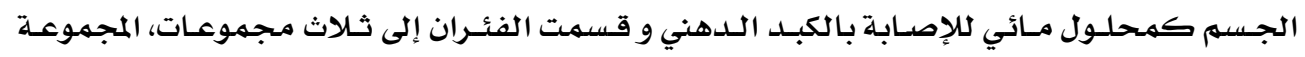

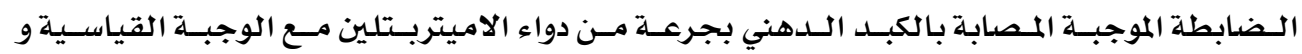

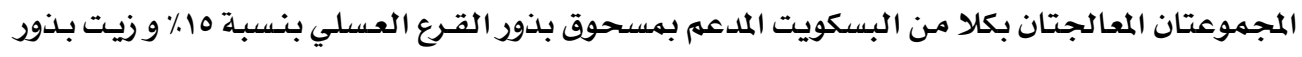

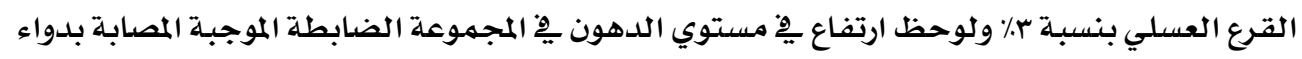

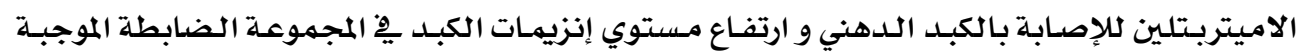

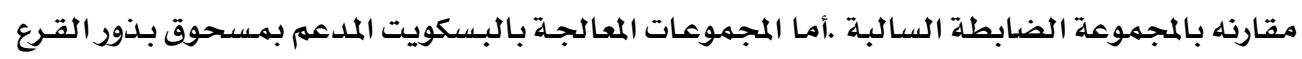

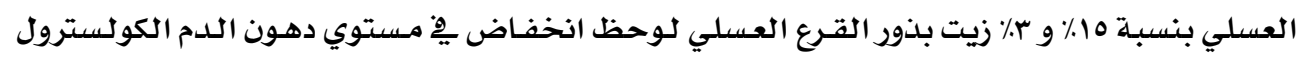

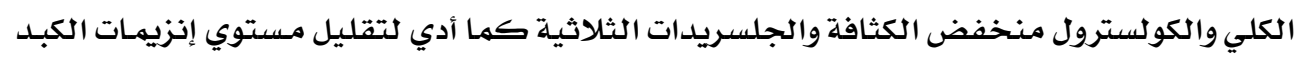

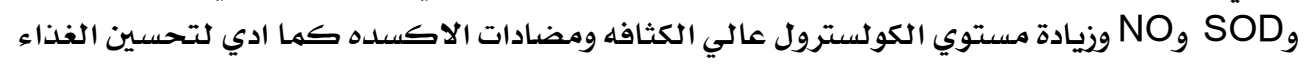

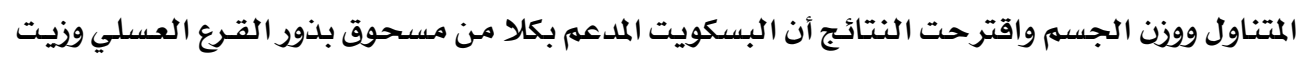

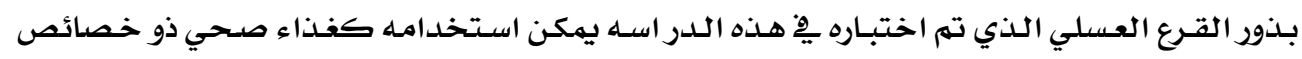
وظيفية لعلاج الكبد الدهني الناتج عن استخدام الدئداره دواء الاميتربتلـين. 